\title{
Effect of Cessation of Anticoagulant Therapy on the Course of Ischaemic Heart Disease
}

\author{
D. E. SHARLAND,* M.B., B.SC., M.R.C.P.
}

Brit. med. F., 1966, 2, 392-393

While fierce arguments have raged round the place of anticoagulants in the management of ischaemic heart disease, evidence has been brought forward that, such treatment having been started, cessation may be hazardous (B.M.F., 1962). A number of reviews suggesting that the stopping of anticoagulant therapy may be followed by an increased thrombotic tendency have been published (Dinon and Vander Veer, 1960; Kuhn et al., 1961 ; Sise et al., 1961) and a possible theoretical basis has been suggested by Poller and Thomson (1964).

Dinon and Vander Veer (1960) reported a series of 20 patients who sustained a myocardial infarction (the first infarction in 18 cases) and reinfarcted within one month of stopping anticoagulant therapy. Anticoagulants had been given for an average period of 40 days (range 24 to 82 days) and in most cases, therefore, the new infarction occurred at a time when the chances of such a relapse were still high.

Kuhn et al. (1961), in a study of long-term anticoagulants in patients who had suffered myocardial infarction, noted a reinfarction rate of $5 \%$ in the month following cessation of anticoagulants-this was higher than in any other month. However, the numbers involved-five reinfarctions (four of which were fatal)-were rather small and could be regarded only as suggestive.

Sise et al. (1961), in a study of a large series of patients who had stopped anticoagulants, noted that among 45 instances where anticoagulants were stopped because of bleeding (and the patient was given vitamin $\mathrm{K}$ or a blood transfusion) there were 20 "relapses" (10 fatal and 10 non-fatal) in the following year, the largest proportion occurring in the first month. By contrast, in 53 instances when anticoagulants were given up because of difficulties in cooperating, because of the necessity for operation and for other non-urgent reasons, there were 15 "relapses" (seven fatal and eight non-fatal) in the subsequent year, and these appeared to be fairly evenly spread.

The difference in the mortality rate in the first month was at the $5 \%$ level of significance, while if all relapses were considered the difference was at the $1 \%$ level.

These observations show that stopping of anticoagulants is associated with an increased thrombotic tendency only when cessation is because of haemorrhage.

\section{Observations}

The present data were obtained during the course of a study of the effects of a low-fat diet compared with an ordinary diet on the progress of ischaemic heart disease. A consecutive series of men were used for the trial. They were all under the age of 65 , had sustained one episode of cardiac infarction, and were subsequently free from serious complications such as persistent heart failure. Cases where the cardiac infarction was thought to be a complication of an existing disease-for example, diabetes or severe hypertension-were likewise excluded. Many of the men received up to 14 weeks' anticoagulant treatment but none were on long-term anticoagulants.

* Present address: Whittington Hospital, London.
It has been shown that there was no significant difference in the progress of the men on normal or low-fat diets (Research Committee, 1965) and, furthermore, there was no evidence of any significant difference in the relapse rate of the men who were on anticoagulants and who form the basis of this study (Table I). Therefore both the low-fat and the normal-diet men have been grouped together.

TABLE I.-Number of Episodes of Reinfarction and Death from Ischaemic Heart Disease Within Six Months of Terminating Full Anticoagulant Therapy

\begin{tabular}{cccc|c|c} 
& & & $\begin{array}{c}\text { Men on } \\
\text { Low-fat Diet }\end{array}$ & $\begin{array}{c}\text { Men on } \\
\text { Normal Diet }\end{array}$ \\
\hline $\begin{array}{c}\text { No. of patients } \\
\text { ", "non-fatal reinfarctions }\end{array}$ & $\ldots$ & $\ldots$ & $\ldots$ & 107 & 116 \\
", "deaths from ischaemic heart disease & $\ldots$ & 11 & 9 & 9 \\
5
\end{tabular}

Special note was made of the duration of anticoagulant therapy, the date on which full anticoagulation was stopped, and the mode of stopping anticoagulants-for example, whether abruptly or over the course of some days. There was no

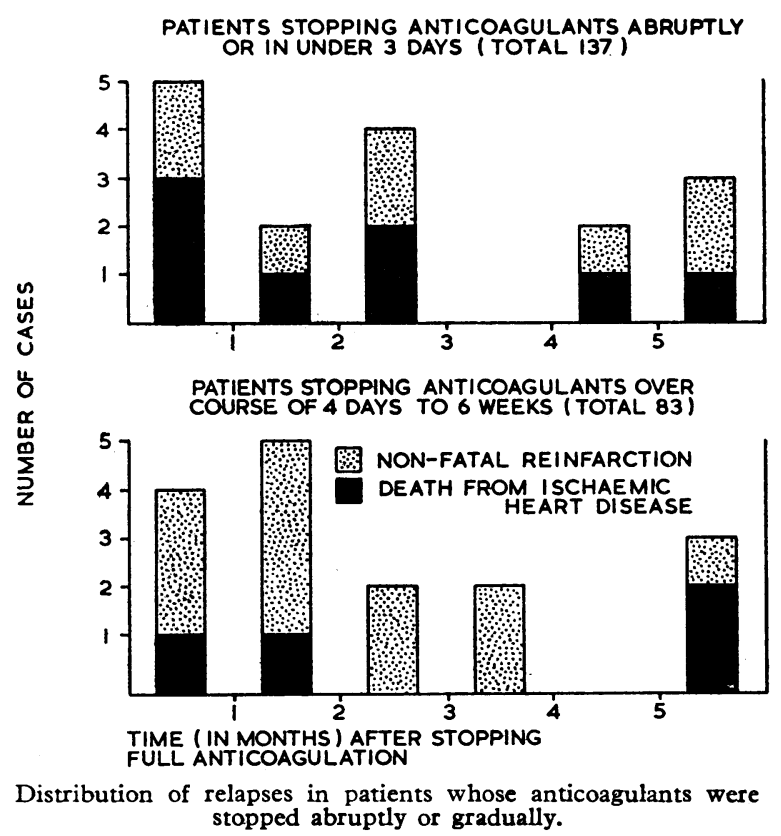

standard way by which the duration of tailing off anticoagulants was fixed.

In all but three cases (when dicoumarol was used) anticoagulation was carried out with phenindione, with the addition of heparin for the first 24 to 48 hours in $70 \%$ of cases. Treatment was controlled by Quick's prothrombin test, a ratio of two to two and a half times the control time being aimed at.

The number of relapses occurring in the first six months after stopping anticoagulants is given in Table II, and their distribution over that time is shown in the Chart. 


\section{Discussion}

The results, as set out in the Chart, may be analysed in many ways. If all those whose anticoagulants were stopped in three days or less are grouped together it will be noted that in the first three months six deaths occurred among 137 patients, while only two deaths occurred among 83 patients tailed off more gradually. This difference, however, is not significant $(0.5>P>0.3)$. Classifying the patients into three groupsnamely, "abrupt terminators," those terminated in one to seven days, and those terminated in 8 to 42 days-it will be seen that over the course of six months six, five, and one deaths occurred in these groups respectively. These differences likewise are not significant $(0.5>\mathrm{P}>0.3)$. If all relapses, fatal and non-fatal, are considered there is still no evidence that stopping anticoagulants abruptly is especially hazardous (Table II). TABLB II.-Number of Episodes of Reinfarction and Death from
Ischaemic Heart Disease Within Six Months of Terminating Full Anticoagulant Therapy

\begin{tabular}{|c|c|c|c|c|c|c|c|}
\hline & \multicolumn{6}{|c|}{$\begin{array}{l}\text { Mode of Termination of } \\
\text { Anticoagulant Therapy }\end{array}$} & \multirow{2}{*}{ Total } \\
\hline & Abruptly & $\begin{array}{l}\text { Over } \\
1-3 \\
\text { Days }\end{array}$ & $\begin{array}{l}\text { Over } \\
4-7 \\
\text { Days }\end{array}$ & $\begin{array}{l}\text { Over } \\
\text { 8-14 } \\
\text { Days }\end{array}$ & \begin{tabular}{|c|} 
Over \\
$14-42$ \\
Days
\end{tabular} & No & \\
\hline $\begin{array}{l}\text { No. of patients } \ldots \\
\text { "., non-fatal reinfarc- } \\
\text { tions . . . } \\
\text { No. of deaths from isch- } \\
\text { aemic heart disease } \\
\text { (with or without coron- } \\
\text { ary thrombosis or myo- } \\
\text { cardial infarction) }\end{array}$ & $\begin{array}{r}85 \\
7\end{array}$ & $\begin{array}{r}52 \\
1\end{array}$ & $\begin{array}{r}34 \\
7\end{array}$ & $\begin{array}{l}15 \\
-\end{array}$ & $\begin{array}{r}34 \\
5\end{array}$ & $\begin{array}{r}3 \\
-\end{array}$ & $\begin{array}{r}223 \\
20\end{array}$ \\
\hline
\end{tabular}

The patients were reviewed with respect to the adequacy of anticoagulant therapy, dosage of phenindione, and duration of anticoagulation (data being available for about $80 \%$ of the group).

All the available prothrombin ratios were considered, except for those recorded in the first week of treatment or where more than one had been carried out in a week: in the latter case only the lowest ratio was noted-for example, ratio of 2.1 out of a series of $2.6,2.1$, and 2.4. When two-thirds or more of the readings were in the therapeutic range-for example, 2 or over-anticoagulation was regarded as satisfactory, but when one-third or less were over 2 anticoagulation was regarded as

TABLE III.-Relapses Occurring Within Six Months of Terminating Full Anticoagulant Therapy, Classified According to Adequacy of Anticoagulants

\begin{tabular}{|c|c|c|c|c|}
\hline & $\begin{array}{c}\text { Inadequate* } \\
\text { Anti- } \\
\text { coagulation }\end{array}$ & Intermediate & $\begin{array}{l}\text { Adequate† } \\
\text { Anti- } \\
\text { coagulation }\end{array}$ & $\begin{array}{c}\text { No } \\
\text { Record }\end{array}$ \\
\hline $\begin{array}{l}\text { No. of patients } \ldots \\
\text { Non-fatal reinfarcts } \\
\text { Deaths from ischaemic heart }\end{array}$ & $26(3 \cdot 8 \%)$ & 50 & $\begin{array}{r}107 \\
8(7.5 \%)\end{array}$ & $\begin{array}{r}40 \\
5\end{array}$ \\
\hline 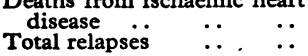 & $\begin{array}{l}1(3.8 \%) \\
2(7 \cdot 7 \%)\end{array}$ & $\begin{array}{l}2(4 \%) \\
8(16 \%)\end{array}$ & $\begin{array}{l}5(4 \cdot 7 \%) \\
13(12 \%)\end{array}$ & $\begin{array}{l}4 \\
9\end{array}$ \\
\hline
\end{tabular}

- Inadequate anticoagulation-one-third or less of prothrombin ratios were 2 or greater.

greater. unsatisfactory (Table III). It will be noted that there is no obvious trend in the relapse rate with varying standards of anticoagulation.

The relapse rate in patients classified according to phenindione dosage is set out in Table IV. The difference in relapse rate of those whose average daily phenindione intake during the

TABLB IV.-Relapses Occurring Within Six Months of Terminating Full Anticoagulant Therapy, Classified According to Average Daily Phenindione Dosage

\begin{tabular}{|c|c|c|c|}
\hline & \multicolumn{2}{|c|}{$\begin{array}{c}\text { Average Daily Dose of } \\
\text { Phenindione }\end{array}$} & \multirow{2}{*}{$\begin{array}{l}\text { No } \\
\text { Record }\end{array}$} \\
\hline & $100 \mathrm{mg}$. or less & Over $100 \mathrm{mg}$. & \\
\hline 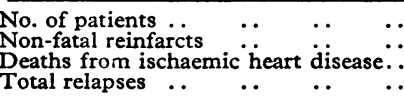 & $\begin{array}{r}94 \\
8(8.5 \%) \\
6(6.4 \%) \\
14(15 \%)\end{array}$ & $\begin{array}{l}83 \\
7(8.4 \%) \\
2(2.4 \%) \\
9(11 \%)\end{array}$ & $\begin{array}{r}46 \\
5 \\
4\end{array}$ \\
\hline
\end{tabular}

TABLE V.-Relapses Occurring Within Six Months of Terminating Full Anticoagulant Therapy Classified According to Length of Anticoagulation

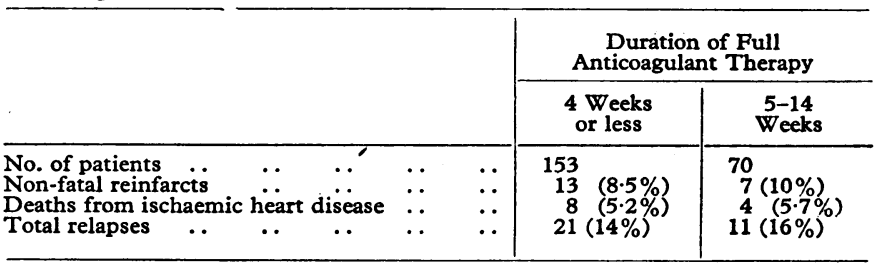

period of full anticoagulation exceeded $100 \mathrm{mg}$. compared with the rest $(11 \%$ compared with $15 \%)$ is not significant $(0.5>P>0.3)$.

Classification on the basis of length of time on full anticoagulation likewise shows no significant association with the rate of relapse in the ensuing six months (Table V).

\section{Summary}

In a study of 223 men who had been on anticoagulants for periods of up to 14 weeks no evidence could be found that abrupt cessation of treatment was more often associated with "relapse" then when treatment was tailed off gradually.

I am grateful to Dr. K. P. Ball for much advice and encouragement and to Dr. J. A. Heady for his guidance on the statistical aspects of this study. This work was supported by a reseach grant from the North-west Metropolitan Regional Board.

\section{REFERENCES}

Brit. med. F., 1962, 2, 659

Dinon, L. R., and Vander Veer, J. B. (1960). Amer. Heart f., 60, 6

Kuhn, P. R., Van Ness, A. L., Jones, R. J., and Bay, E. B. (1961). Arch. intern. Med., 108, 884.

Poller, L., and Thomson, J. (1964). Lancet, 2, 62.

Research Committee (1965). Ibid., 2, 501.

Sise, H. S., Moschos, C. B., Gauthier, J., and Becker, R. (1961). Circulation, 24, 1137. 